\title{
Legitimacy of Death: National Appropriation of the Fallen
}

\begin{abstract}
:
Many influential theorists of nationalism see war as a social conflict that to great extent homogenizes and unifies the nation. Nowhere is that unity more clearly expressed than in war memorials and cemeteries. This article will consider the example of Britain and the USA in the aftermath of the WWI in order to examine how the state legitimized its ownership of the bodies of its dead soldiers. It will argue first, that in an internal dispute, when all sides share a normative ideology, nationalism cannot offer an effective basis for legitimacy. Second, it will show how in the aftermath of WWI, the bodies of the soldier dead were not symbols. In order to transform a dead body into a symbol, this article concludes, the body first has to be 'deindividualized.'
\end{abstract}

\section{Biographical Note:}

Dr Gordana Uzelac is currently a Senior Lecturer in Sociology at London Metropolitan University. Her research interest is focused on theories of nations and nationalism, and she is currently working on economic nationalism. 


\section{Legitimacy of Death: National Appropriation of the Fallen}

Dead people belong to the live people who claim them most obsessively. ${ }^{1}$

Nationalism, as Gellner teaches us, has a 'natural' predisposition toward a state. He defines nationalism as a theory of political legitimacy 'which requires that ethnic boundaries should not cut across political ones' (Gellner, 1983: 1). Notions of popular sovereignty, rule by and for the nation, national interests, and national character are all ideological formulations utilized for legitimizing the state. The ultimate sign of nationalism's power can be found in the belief that every citizen should be ready, if not to die, then definitely to kill for their nation-state. This ultimate sacrifice is sanctified by many national monuments, myths and popular songs.

In this paper I will focus on the so-called internal legitimacy, that is, legitimacy based on 'subjective beliefs of individuals and groups in the normative validity of a particular political order' (Malešević, 2002: 85). I will choose a particular case study in order to investigate how and in which social circumstances nationalism legitimates a regime and its rule. This will be done from a Weberian perspective, where legitimacy is seen as a political relationship between the state and its subjects, and where the state both interprets and defines its rights, while its subjects' believes confirm or not legitimacy of state in exercising those rights (Barker, 1990). 
War is a social condition that can be seen as the ultimate test of state legitimacy. After all, the popular belief says wars break and make states. First World War had probably the greatest impact on nationalism as an ideology and movement in Europe. As Mosse (1990) tells us, this war and its almost universally tragic consequences nationalised the masses of Europe. I argue that it also nationalised states. Any state that loses millions of its citizens will face a crisis of legitimacy, forcing a regime to employ various methods and techniques in a search for legitimacy. As we know, in the aftermath of the WWI many regimes failed in this task. Yet most of the victors were quite successful in surviving this test, at least for a short period of time.

The processes through which European masses are nationalised are discussed in many volumes. I will ignore this issue in the current discussion. In examining the interplay between nationalism and legitimacy, I am more interested in how the state defines and justifies its rights, and how, and to what extent, the search for legitimacy in the exercise of that right relies on the ideology of nationalism. While the state's right over the lives of its subjects seems undisputed, the nature of the WWI brought the issue of 'who owns the dead' to the fore for the first time. This paper will consider the example of Britain in the aftermath of the WWI in order to examine how the state legitimized national appropriation of the fallen, that is, how the state legitimized its ownership of the bodies of its dead soldiers. To identify the main processes by which states' rights to the dead were legitimized, the British case will be compared with that of the USA. The main analysis will be based on transcripts of British parliamentary debates in the period from 1919 until 1921 and analysis of newspaper articles published in The Times (TT) over the same period. In the comparative case of the USA, the analysis will focus on articles from The New York Times (TNYT) over the same period. 


\section{The Context}

In the summer of 1914 nobody could have predicted the devastation that the Great War would leave behind. A century later, we can only estimate the number of people killed over its four years. ${ }^{2}$ Overall, it is estimated that 8.5 millions of people been killed on all sides. Allied casualties are estimated at five millions killed, out of which Russia claimed the highest number of 1.7 million, closely followed by France with 1.3 million and British Empire of 908,371 dead (702,410 for the UK alone). Data for the American casualties vary greatly: from 50,585 to 116,516 depending on the source.

The sheer number of soldiers killed and the vast geographical reach of the war's many theatres forced states to establish special institutions that could locate, register and bury their dead. In April 1915, the British Government established the Grave Registration Commission (TT, 16/4/1915). On the recommendation of this body, in May 1917, a Royal Charter established the Imperial War Graves Commission (the Commission in further text). On 24 November 1918, France followed British example when a Commission on Military Cemeteries was established (Winter, 1995: 24). In December 1917, seven months after the USA entered the war, establishment of the Graves Registration Service was announced, 'a branch of the army whose sole duty is to arrange for the proper burial of our soldiers who die in France' (NYT, 14/12/1917).

None of these institutions had an easy task. On 23 August 1921, The New York Times reported that 'originally there were about 2,400 burial places for American soldiers in Europe, with about 15,000 isolated graves'. By 1918, the Commission reported that 'some 587,000 graves had been identified and a further 559,000 casualties were registered as having no known grave' (http://www.cwgc.org). On 9 April 1919, it was reported to the House of Commons that there were 'something like 1,000 cemeteries in France' alone and how 'those 
who are lying [in isolated] graves, numbering about 150,000, are being gathered together in large cemeteries' (HL Deb 09 April 1919 vol 34 cc 231). The French Government had to make proper arrangement for a 'masses of fragmentary, unidentifiable remains and with an enormous number - a later report put it at 200,000 - of isolated graves' (Sherman, 1998: 451). These numbers indicate what kind of task lay ahead for the British, American, and French governments in a country devastated by four years of war. The establishment of these commissions, which had as their sole task the organisation of burials and maintenance of cemeteries, clearly signalled that the states are taking full responsibility for the bodies of their soldier dead.

In pursuit of this task, Allied governments established their policies regarding the treatment of the dead. While, in France, no clear policy regarding the burial of dead soldiers existed during the war, Winter (1995) gives examples of how official requests received from relatives to exhume their sons and husbands and bury them at home were systematically refused. With the formation of the Commission on Military Cemeteries, the French government issued a proclamation according to which 'no private exhumations and reburials were to be allowed' for the period of three years (ibid.). In June 1919 however, the Ministry of War proclaimed a seemingly final ban on all exhumations in the Zone of Military Operations (ibid.: 25). Just a year later, and under the pressure from various organisations and bereaved family members, the French government changed its mind by 'establishing the right of families to claim the bodies of their loved ones, and to transmit them home, at state expense' (ibid.: 26). Winter (ibid.) writes that in 1922 'about 300,000 of the dead ... actually went home', that represents around $40 \%$ of those identified bodies. Hence, after a long and painful public debate and under a great pressure, the French government acknowledged the primacy of the bereaved family in claiming their dead. 
In 1917, and under great pressure of those strongly opposed to American involvement in the war, the American government issued a statement in which it promised that all of its military dead will be returned home (Sledge, 2005: 135). At the end of the war, in the moment when numbers of American casualties were counted, the American public and government found themselves divided on the question of whether their dead soldiers should be repatriated to the USA or buried in France. In January 1920, constrained by their earlier promise, the War Department found the solution by polling the dead's next-of-kin as to whether their relatives should be repatriated or buried in France. On 24 January 1920 The New York Times published the official results of this poll: 'there were 74,770 cards sent out, and so far 63,708 answers have been received [...] requests for return 43,900 (68\%); requests for retention in Europe $10,400(30.6 \%)^{\prime}$. Those bodies claimed by the next-of-kin would eventually be returned for a burial arranged by the family, or, if they wished, in Arlington National Cemetery. This act established US Government policy, according to which 'the next of kin had, within certain parameters, final authority as to the disposition of remains' (Sledge, 2005: 141).

Seemingly, the British government easily resolved this same problem. Early in 1915, it proclaimed that no bodies would be returned home, at least for the duration of the war (Bourke, 1996: 225). In its report of 29 November 1918, the Commission explained that ' $[t]$ he removal of the bodies to their native countries is strongly desired by the relatives in a small number of cases' (TT, 29/11/1918). Hence, the Commission 'felt that a higher ideal than that of private burial at home is embodied in these war cemeteries in foreign lands' (ibid.). The government's control over its dead soldiers was finalized when the Commission assumed full responsibility over the arrangement of cemeteries. Unlike the French and American governments, the British gave practically no concessions to the bereaved families. It clearly proclaimed its full ownership over its dead soldiers' bodies. 
In spite of states' different policies toward the return of their war dead, all three governments adopted the same principle for the treatment of those buried in the military cemeteries. The main principle was the 'equality of treatment ... expressed by uniformity of design' (HC Deb 04 May 1920 vol 128 c 1932).

In the spirit of this principle, in Britain the Commission decided that in military cemeteries abroad 'individual headstones of a single unified pattern' (ibid.) should be erected for all of the dead. Beside the badge of regiment, 'on each headstone there will be inscribed the appropriate religious symbol' (TT, 6/12/1918). The Commission allows relatives 'if they so desire, to have inscribed, at their own cost, a short text or verse chosen by themselves' (ibid.). In each cemetery 'there should stand a Cross of Sacrifice and an altar-like Stone of Remembrance' (TT, 17/2/1919). In effect, the Commission decided to create a series of 'great National Memorial[s]' where the uniformity of design would ensure that 'the fellowship of the War [would] be perpetuated in death' (HC Deb 04 May 1920 vol 128 c 1932).

The consequences of the policies adopted by the UK, French and American governments are well known. Mosse (1986, 1990), Winter (1995), Gregory (1994), Fussell (1975) and many others have dedicated numerous volumes in which the meaning and symbols of states' Great War cemeteries are interpreted and explained. Even today, the fields of uniform headstones are images deeply imprinted on our consciousness. It is precisely these uniformed headstones that force us to perceive these cemeteries as representations of a collective, where all individuality of death is lost. From these works we know that this uniformity of graves is supposed to symbolize national unity and the equality, in death if not in life, of those who died for a common cause. We know that these cemeteries are supposed to arouse, in every member of the nation, a deep gratitude for those who fought and made the ultimate sacrifice for their and our nation. And if we know all of this, we too are the victims of nationalisation of the masses (Mosse, 1990). 
Yet even if these war cemeteries successfully nationalise us, at least one question still remains: is this nationalisation an intended or unintended consequence? In other words, how did the Allied governments legitimize the creation of the uniform war cemeteries? How did it happen that in the period of 1919-1921 the state managed, or was allowed, to appropriate the fallen, to collectivize individual deaths? The brief overview of official policies sketched above reveals that each government assumed a different position regarding the crucial issue that made this transformation of a dead body into a monument possible, that is, the question of who owns the dead.

\section{Appropriation of the dead}

Following Weber, the basis of legitimacy of a modern nation-state should be found in its legal-rational authority. This could be crudely interpreted as a position where the state claims legality and superior knowledge in making certain decision, and where its subjects believe in the legality of their government's decisions and acknowledge its epistemic authority.

As a starting point, let us examine the legality of states' appropriation of the war dead. Rohan Hardcastle (2007), in his book Law and Human Body, examines in some detail the question of 'do you own your body' and immediately answers: 'it is not possible to say that we "own our entire bodies"' (ibid: 15). Apparently this statement is based on a principle of defining property: 'One cannot possess something which is not separate nor distinct from oneself' (ibid.). The judicial recognition of the 'no property' law was established in 1794. Since then, English Common Law has maintained that dead bodies cannot be subject of property laws, invoking the criminal law to provide for their protection (ibid). Yet in 1882, it recognized 'duties to bury corpses and concomitant rights of possession over corpses'. Hence it established that 'the deceased's executors' have a right of possession until the corpse is 
buried, but have no property in it' (ibid. 47). Finally, the same law states that 'parents lose any right to possession for burial once the body has been buried' (ibid.: 49). It seems clear that according to the English Common Law, the bereaved families of the WWI soldier dead had no legal rights to claim their bodies for burial. In 1919, all soldiers killed on the Continent have already been buried. By default, the British government acted according to the law, though, as we know, legality and legitimacy are two quite distinct phenomena.

As McEvoy and Conway (2004: 546) claim, the "narrow private law of ownership fails to take account of the centrality of the dead as sites of important political and ideological conflicts'. And indeed, as soon as the Allied governments proclaimed their policies regarding the return of the dead, the legality of their decisions was contested on both grounds. In the USA, those who argued for national appropriation of the dead were in opposition to the government's decision to bring the dead back to their families. Bishop Charles H. Brent, senior Chaplain with the American Expeditionary Forces in France, described these dead as 'that sacred dust which though mingled with the soil of France, is forever American' (TNYT, 16/1/1920). General Pershing also opposed bringing dead home since 'the American dead in [French] soil would always be a reminder of how the two nations had fought together' (TNYT, 1/8/1919). A few months later, the sentiment was repeated by General O’Ryan: 'as long as these graves remained in France their occupants would continue in no small measure to do what they were doing - what they gladly, proudly, and gloriously did - when they gave their lives: they would still be serving their country' (TNYT, 19/12/1919). The dead soldiers seem still to be soldiers. The fact that these soldiers are in the form of 'sacred dust' did not grant them automatic demobilization. This claim over the dead was clearly justified by national interests and the state's international politics. No wonder Ron Robin (1995: 55) argues that American military cemeteries on foreign soil 'were designed primarily as a political "foothold in Europe". 
On 9 April 1919, on the other side of the Atlantic, the House of Lords held a discussion on War Graves (HL Deb 09 April 1919, vol 34, cc 223-40). In this debate, the Earl of Selborne directly opposed the state's right to possess its dead soldiers, either on legal or political grounds: 'It is not the regiment, it is not the Government or the nation, still less is it a Public Department or Commission, that ought to have the last word in this matter, but the father, the mother, or the widow' (ibid., c 234). The claim that 'the dead is the possession of the family, and that no one else has a right to say a word as to the disposal of the dead or the treatment' is apparently 'at the very bottom of the English character' (ibid., 235). In the same debate Lord Phillimore seconded the argument and accused the government of having 'prevented ordinary Englishmen from exercising their ordinary rights'. In the debate held on 4 May 1920, Viscount Wolmer stated how '[i]t is so natural that we should look on our dead as belonging primarily to us as individuals' (HC Deb 4 May 1920, vol 128, c 1943). Even though these MPs invoked a 'right', it was not a right based on a specific legal document or governmental policy, but on notions of 'being natural' or part of the 'English character'. The Government's appropriation of the dead was called 'bureaucracy run mad' (ibid., 235), and a 'heartless official action' (HC Deb, 17 December 1919, vol 123, c 486) as its main opponents countered the power of legal-rational authority with the authority of tradition.

It seems this traditional argument challenged the legitimacy of the state's appropriation of the dead in practice as well, since 'not all corpses were allocated the same status' (Bourke, 1996: 236). Bodies of soldiers who, for some reason, died on British territory were not claimed by the state. In these cases the family's right of possession was not contested. All details of the burial - its location, headstone, and ceremony - were firmly under the family's control. The British government clearly adopted two separate policies regarding its war dead: one for those killed in foreign lands, and one for those who died on British soil. Such diversity of treatment seems to indicate that even the state recognized the power of tradition over legality 
when it gave bereaved families rights over the bodies of those who died on British soil. It is therefore necessary to examine in more detail how governments searched for legitimacy by denying that priority and appropriating the bodies of the fallen on foreign soil. The literature on war memorials and the commemoration of the war dead teaches us that nationalism as an ideology should be the main source of this legitimacy.

\section{Nationalisation of the dead}

The following analysis of the justifications applied to the appropriation of the dead will focus on the rhetoric, vocabulary and symbolic expressions used by British officials responsible for the creation of the policy toward the war dead and American leaders of opposition to the official policy.

The main official justification of the policy of equality through uniformity was, first of all, found in the celebration of the value of national unity. As one state official claimed, the principle celebrated a specific 'genius of the war' defined as 'the solid and united effort, embodying its unity in forces drawn from every island and continent under the British Flag, fused and welded into one ... ready to die, and dying for one common cause that they all understood' (HC Deb 04 May 1920 vol 128 c 1932). Even though this justification of equality through uniformity was identified as a property of the war itself, its meaning was clearly grounded in typical nationalistic discourse. It followed quite common view (see, Smith 1999, Hutchinson, 2007) that war memorials and remembrance ceremonies contribute to national homogeneity and strengthen national solidarity. Analysing the effect of Remembrance Day, Smith (2003: 249) concludes how these ceremonies evoke 
sacrifice made by so many young men, which serves to inspire the survivors to work for a happier and more peaceful destiny for the nation, so that these dead "shell not have died in vain."

By definition, the war dead are those who willingly gave their lives in defence of that common cause. They are seen as embodiments of 'ethical parameters that determine future actions as they bind posterity in moral obligation to dead heroes' (Malešević, 2010: 185).

The second consideration is found in 'a peculiar feature about our Army', characterised by 'a spirit of brotherhood and comradeship which levelled all ranks and distinctions' (HC Deb 04 May 1920 vol 128 c 1932). The principle of equality through uniformity, in this view, celebrates the value of solidarity; or as Mary F. Watkins described in her letter, 'the loveliest fruits of that dreadful harvest' (TNYT, 20/4/1921): the comradeship between soldiers. While this sense of comradeship is an expression of 'micro-level solidarity of a small-group bond' (Malešević, 2010: 223), it is now transformed into a property of an institution - the Army, and, more specifically, of 'our Army'.

The appropriation of the dead also aimed to celebrate the value of social equality when the Commission felt it needed to take into account 'the difference between rich and poor'(HC Deb 04 May 1920 vol 128 c 1932), a civilian translation of the military distinction between officers and men. The policy adopted for cemeteries abroad not only promoted equality in death, but also hid inequalities in life. While these distinctions could not be made invisible on local cemeteries in Britain, where family's class and status determined the size and design of the headstone, cemeteries abroad could promote an ideal picture of truly national equality. ${ }^{3}$ As Robin claims, 'equality of death, like equality in life, could only be achieved by the exercise of the power of the state' (1995: 64-5). 
Beside the three main justifications, which invoked values of unity, solidarity and social equality, government officials employed several techniques that secured a total appropriation of the dead.

The Commission and those who supported it frequently claimed that their policy reflected 'desires of the dead themselves' (TT, 17/2/1919). Major Cohen, for example, urged his peers in the House of Commons to consider the issue from 'the point of view of the men who lie there now' (HC Deb 17 December 1919 vol 123 c 492). Mr Thomas is certain that 'they are buried as they desired to be' (HC Deb 04 May 1920 vol 128 c 1950). As Katherine Verdery (1999: 29) argues, ‘[d]ead bodies have [a] ... great advantage as symbols: they don't talk much of their own (though they did once). Words can be put into their mouths ... or their own actual words can be ambiguated by quoting them out of context'. Ventriloquation of the dead effectively appropriates their thoughts and wishes.

National appropriation of the dead appropriated the emotions as well, and this was achieved at the expense of the emotions of individual mourners. On 12 December 1918, The Times admitted that a 'censorship on sentiment is abhorrent', but explained that the Commission's principle of uniformity is only meant 'to restrain the expressions of grief and affection for the dead within the limits of what is permissible in a public memorial'. The fact that an official policy censored emotions does not mean that the appropriation of the dead was cleansed of all emotions. On the contrary, the Commission was certain that 'proper emotions' could only be aroused through a particular aestheticization of the national monument built on the dead bodies. 'These uniform headstones', the Commission explains, 'will at once perpetuate the impressive effect' and 'will strike the note of dignity and solemnity suitable to a cemetery, accompanied by the spirit of hopefulness and pride proper to the resting places of those who have died with glory and not in vain' (TT, 27/11/1918). It seems that the intended affect was accomplished. In a series of articles published from June 1919 until May 1921 The Times 
brought several reports from its special correspondents who visited cemeteries designed and maintained by the Commission. Those who themselves experienced the impact of the principle of equality through uniformity described a 'picture of quiet and reposeful ... peaceful and serene beauty' (TT, 4/6/1919). The Times' correspondents tried to assure the relatives of the dead that once the cemeteries were completed 'there will certainly be much in it of noble dignity, quiet grandeur, and solemn peacefulness' (TT, 5/2/1920). These reports supposed to testify on the effectiveness and affectedness of the appropriation of the dead. They also could be seen as offering some comfort to bereaved families whose private emotions of grief and sorrow were suppressed for a greater ideal. Meanwhile, on the other side of the Atlantic, one such visit to the military cemeteries of the American soldier dead in France produced quite an opposite effect.

In April 1921, when the American government was well on its way of fulfilling its promise to bereaved families to return their dead home, Owen Wister and Thomas Nelson Page visited some of these cemeteries in France. Appalled by what they had apparently seen, they wrote letters to The New York Times published under the title 'Plead for our Dead in France' (TNYT, 15/4/1921). In his letter Owen Wister shocked the American public when describing a sad 'sight of our cemeteries; from whose peaceful decent dignity the bones of our soldiers ... are being daily torn up' (ibid.). He continued:

There were no coffins - there could be none. Bodies were sometimes wrapped in blankets and sometimes put in baskets. Mud has filled these baskets and in winter has frozen to a hard cake. Those who take this mass up often place the basket on top of a stove to melt the mud off and find something left to send to America. This something cannot be embalmed. It is sprinkled with disinfectant and shipped to Hoboken [port]. ... Piles of these poor fragments of human beings lie at Hoboken unclaimed (ibid.). 
In their letters Wister and Page used de-aestheticization of military cemeteries as a means to delegitimize the government's policy of returning the dead. Even though state officials later refuted almost all of Wister and Page's claims (TNYT, 8/6/1921), The New York Times $(15 / 5 / 1921)$ reports 'a sudden shift in sentiment toward leaving the bodies of American soldier dead in cemeteries in France'. It seems that both aestheticization and deaestheticization were used to justify national appropriation of the dead.

This brief summary shows that the state justified its policy, not on particular laws or regulations, but predominantly on a set of carefully selected values and prescribed symbolic expressions of those values. The appropriation of the dead was designed as a total appropriation: it claimed soldiers' dead bodies, thoughts and emotions, it interpreted their wishes and nationalised their loyalties and solidarities. If this analysis ended here, it could be seen as confirming the prominent role of nationalism in legitimizing the creation of the 'cult of the fallen soldier' (Mosse, 1990). It would be easy to claim that the state officials attempted to legitimate their decisions not on the basis of legal-rational justifications, but rather on the basis of value-rational ones, ${ }^{4}$ those clearly defined by dominant nationalist ideologies. However, the Weberian tradition teaches us that the authority's appropriation and justification of its rights is conditioned by those who are subject to that authority, and quite a few British subjects and American citizens contested their governments' authority in defining ultimate values.

\section{Individualisation of the dead}

Every public statement of the Commission regarding the treatment of their dead soldiers provoked strong public reaction. The most notable signs of opposition to the government's policy were published on the pages of daily newspapers and voiced in parliamentary debates. 
In the period of October 1918 until November 1921, The Times alone published more than thirty letters to the editor that directly addressed the issue of war graves. In the same period, the houses of parliament held three sessions on the issue. There were few speakers in these debates who did not report receiving numerous letters from bereaved families and old and newly formed civic organizations, from various veteran organisations, to the union of undertakers.

Public reaction focused on two issues: contesting the principle of the state appropriation of the dead in general, and contesting national appropriation of the dead. The arguments of the opposition directly contested the legitimacy of the proposed policy and its main principle. And since the state searched for legitimacy in the domain of ultimate values, these values found themselves under direct attack.

While it would be difficult to find single opponent of British policy who publicly contested the value of equality, one of the main targets of the opposition was that of uniformity. On 9 April 1919 in a House of Lords debate Lord Balfour of Burleigh asked: 'why it is necessary that the headstones should be absolutely uniform' (HL Deb 09 April 1919 vol 34 c 225). The principle of uniformity was easily disqualified as legitimate with few carefully chosen labels and metaphors. It was referred to as 'the hateful idea' (ibid: c 233), as 'inadequate, monotonous, and unsightly’ (TT, 24/7/1919), 'well-drilled patterned uniformity’ (TT, 23/12/1919). A cemetery based on the principle of uniformity is also equated with 'a line of milestones' (HL Deb 09 April 1919 vol 34 c 225), 'a dog's cemetery’ (HC Deb 17 December 1919 vol 123 c 485) and the convicts' cemetery in Dartmoor (ibid: c 488) and described as 'the cannon fodder of a triumphant militarism' (TT, 3/5/1920). A letter to The Times wrote: 'English men and women still have a craving for liberty; they do not appreciate having everything settled for them in German fashion' (TT, 23/12/1919). In these speeches and 
letters uniformity was confronted by another value interpreted as closer to the English 'national character' - that of individuality.

Individualism, some MPs claimed, is embedded in the same act of death. Cecil (HC Deb 17 December 1919 vol 123 c510) asked: 'What is the great characteristic of death?', and answered: 'it is the naked personality which stands alone at death as never before in life' (ibid.). Hence, 'all symbolism in a graveyard ought to express that characteristic, and to submerge it in a national uniformity, one stone exactly like the other, is to miss the whole beauty and pathos of death' (ibid.). The opposition directly denied the government's right to 'dictate to other people as to how their nearest and dearest shall be commemorated' (ibid: c502). Instead, they claimed that in these cemeteries '[e]verything should speak of the personality of the individual, and nothing that can be avoided of the uniformity of the organisation by which they are erected' (ibid.: c511).

By denying the state a right to collectivize individual graves, the opposition also questioned the state's right 'to take the bodies of the dead to form part of a war memorial' (ibid., 509). Cecil exclaimed: 'This is not a war memorial at all; it is a cemetery of the dead' (ibid.). Here a distinction is made between a national and personal commemoration. The opposition had no problem in allowing the government to 'put up any war memorial they like in France, but they have no business to use the individual body of the individual soldier for that purpose' (ibid.).

Finally, the principle which gives priority to the state or any institutional interests, over the bereaved families was, according to Cecil, 'utterly without ethical defence' (ibid: c509.). It was a position which 'disregards the tenderest feelings of humanity merely to pursue a bureaucratic ideal' (ibid.). The legitimacy of the government's policy regarding the war graves was thus attacked within the frame of binary opposition between a 'bureaucratic 
ideal', defined as unethical and stripped of all emotions, and that 'what is right' - an ethical position that respects tradition, individuality and sentiment of the bereaved families.

Once the main principle of equality through uniformity was delegitimized, all other values that the Commission defined as the basis for their proposed policy became contested as well. The idea that the uniformity of headstones would symbolize comradeship was seen as redundant since ' $[\mathrm{d}] \mathrm{o}$ they not all lie together, shoulder to shoulder, near the field of battle where they fell' (HC Deb 17 December 1919 vol 123 c502). While the Commission claimed that the wishes of the dead could be interpreted through the wishes of their living comrades, Cecil warned that 'they can only speak for themselves' (HC Deb 04 May 1920 vol $128 \mathrm{c}$ 1963). The opposition effectively claimed that 'It really is not right to play with people's feelings in order to produce an artistic effect' (HC Deb 17 December 1919 vol 123 c489). Moreover, the opposition argued that the memory of the glorious dead does not depend on memorials: 'It is a delusion ... that you can affect the memory of deeds like these by anything you do in stone' (HC Deb 04 May 1920 vol 128 c 1962). For opponents of British policy, issues relating to the war dead 'touch the very depths of emotion, and cannot be treated officially and bureaucratically at all' (ibid.). This statement expressed the essence of the state's problem of legitimacy in its appropriation of the dead. A modern nation-state cannot but be seen as the embodiment of the legal-rational authority, characterised by its efficient bureaucratic apparatus. It is therefore by definition seen as incapable of dealing with matters of emotions. For oppositional voices, matters of emotion should have been left to the institution most able to handle them - the family.

The Times, and other British daily newspapers, opened space for some of those voices of the bereaved family members. The great majority of the letters published in The Times showed strong opposition to the official policy on war graves. However, very few contested the state's general principle. They were mainly opposing national appropriation of the dead. In 
general, the bereaved family members wanted a headstone 'more symbolic of the faith in which their children died' (HC Deb 17 December 1919 vol 123 c497). The Commission was accused to advocating the erection of headstones that 'discourage the prominence of the Cross' (HL Deb 09 April 1919 vol 34 c240). In her letter of 29 March 1919, Lady Florence Cecil explained that it was 'through the strength of the Cross that many of them [who gave their lives] were enabled to do so. It is only through the hope of the Cross that most of us are able to carry on the life from which all the sunshine seems to have gone, and to deny the emblem of that strength and hope adds heavily to the burden of our sorrow' (TT, 29/3/1919). 'A War Widow' asked: 'Are we really asked to attach more importance to the inscription than to the cross, and to reject the true emblem of Christianity because it is not designed to stand the wear of ages?' (TT, 7/6/1919).

Reading these views, one could assume that the Commission's proposal was stripped of all religious symbolism. Burke (1996: 225) claims that the Commission introduced the idea of uniform headstones in order to "cater to the variety of religious beliefs amongst the servicemen as well as impose an aesthetic discipline'. 5 The solution was found in the uniformity of headstone's shape, but with possibility of inscribing desired religious symbols. Yet, while it seems quite obvious that the Commission's proposal built strongly on the religious symbolics, it is still perceived as not religious enough.

Mosse (1990: 7) teaches us that at the end of the WWI 'the cult of the fallen soldier became a centrepiece of the religion of nationalism'. While we today could easily see merit in this statement, the views of those who opposed the government's treatment of the dead in the aftermath of the war reveal that the transformation of nationalism into a civic religion was not an uncontested process. Post-WWI nationalism did not operate in an ideological vacuum. It had to face religious beliefs and its long traditions embedded in British culture. Nationalism and religion are not mutually exclusive, but the 'issue of the Cross' shows that nationalism 
rarely substitutes for religion. This is particularly clear when the issue of death is in question. While the life of the fallen is given to the nation, their death still belongs to their religion. For the majority of bereaved family members, the salvation and resurrection of a dead soldier was not accomplished through the nation, but through the Cross.

The analysis so far shows that both the government's representatives and their opponents subscribed to a central nationalist discourse. It shows that both parties wholeheartedly accepted the narrative in which 'those who died for their nation' earned equality of treatment. Both claimed the authority to define the ultimate national values that should be celebrated in those cemeteries of national heroes. But the 'potency of nationalism comes from its ability to adapt and metamorphose so as to dovetail with distinct and often contradictory official doctrines' (Malešević, 2006: 84). Nationalism in action emphasizes the value of uniformity while at the same time emphasizing the value of individuality. Nationalism is evoked when it demands a total appropriation of the dead, just as when it is satisfied with appropriating the living.

This analysis also shows the futility of the value-rational justifications that nationalist ideologies readily provide. In a situation where both sides in a conflict claim to speak for the nation, values lose their power. So what really legitimized the state's appropriation of the dead?

\section{Instrumentalisation of the dead}

In the parliamentary debates that discussed the Imperial War Graves Commission's reports, Winston Churchill - in a double capacity as the Secretary of State for War and as a parliamentary representative on the Commission - was one of the main defenders of the 
Commission's proposal. In his speech of 17 December 1919, Churchill clearly emphasized that the matter of war graves was such that it could only be 'treated administratively on certain broad general principles' (HC Deb 17 December 1919 vol 123 c505). He reminded his listeners that only '[t]he power of a great State operating over the centuries' could build 'unique memorials'(ibid., c508).

Six months later, in the same session of the House of Commons where Cecil and Wolmer systematically de-legitimatized most of Commission's justifications, Churchill's speech ended the debate. From the beginning, Churchill warned his fellow members that for a moment he would have to 'dwell upon the practical aspect of the case' (HC Deb 04 May 1920 vol 128 c1967). Practical concerns started with the fact that there were 500,000 graves to be dealt with in France and Flanders alone. Churchill painted a picture of the technical and practical issues that the Commission faced. These included the fact that 'the means for making tombstones in this or any other country are limited', 'these memorials [have to] $\operatorname{arriv}[\mathrm{e}]$ at the graveyards at the same time so that the work can be immediately undertaken and the graveyard brought into complete existence. Many of these places ... are situated in the desolate war-shattered wildernesses of the Western Front, 10 or 20 miles from the present habitations of men. It is necessary that the working parties engaged on this work shall be fed, housed and maintained ... and it is absolutely necessary that ... the memorial shall arrive at the right time ... so that the work can be completed as speedily as possible'. Hence Churchill warns that ' $[\mathrm{e}] \mathrm{ven}$ with this strict standardisation ... it is calculated that more than ten years will elapse before this task can be completed. If there was to be extra complexity in this task, [and] relatives were to ... produce independent memorials, you', Churchill warned, 'would not get these graveyards finished within the lifetime of the present generation'. He is sure that injury that the relatives would suffer in this situation is "more serious ... than that suffered by the restrictions on individual choice' (ibid.). 
In defence of the proposed shape of the headstone Churchill demonstrated that 'more written matter can be contained within the limits of space allowed on a stone of this shape than on any other form of stone which can be devised' (ibid., c1968). The use of 'a cruciform headstone' Churchill assured, is 'impracticable. Either the stone so finished would cost more than the present uniform stone, or else it would be of a flimsy character which would, in a few years, be defaced by time' (ibid.).

When these debates around the war graves are chronologically examined, Churchill's speech seems to have offered a basis for legitimacy of the appropriation of the dead on which the majority could agree. In this justification the contested principle of uniformity was not an expression of equality, but of expediency. It was not a celebration of comradeship, but craftsmanship. It might not be aesthetically appealing, but was technically necessary. It was not, therefore, nationalisation of the dead that legitimised their appropriation by the state, as Mosse and others would like us to believe, but their instrumental rationalisation.

\section{Who Owns the Dead?}

Ernest Gellner (1997: 25) tells us that in the modern age nationalism is one of the two main pillars of political legitimacy. Rather than taking Gellner's word for granted, I have tried to test his claim in a particular case study, a case often described as nationalism's pinnacle moment.

On a normative level, nationalism, as with any ideology, 'presents a relatively clear and uncompromising set of ethical prescriptions which are in large part derived from concrete knowledge claims of “given” moral absolutes' (Malešević, 2006: 92). During the Great War, and with a full support of the state bureaucratic apparatus, nationalism undoubtedly 
succeeded in strengthening macro-level cohesion and homogenisation. As such, on a normative level, nationalism as ideology proved to be rather efficient in legitimizing a war against the national Other, or as British liked to call it - the Hun.

If nationalism, as Gellner teaches us, is a pillar of political legitimacy, it can only provide value-rational legitimization. But on an operative level, 'the concepts, ideas, values and practices $[\ldots]$ can never be ultimate, final or uncompromising' (Malešević, 2006: 92). On this level concepts and values presented are 'intentionally formulated with the aim of justifying a particular course of action ... or to legitimise or de-legitimise particular policies' (ibid.). The domain in which the government's appropriation of the dead had to be legitimized is characterised by 'a constant value dynamism where different images of the world and different diagnoses of reality compete for the "souls" of each and all' (ibid.: 93).

Nationalism, as Breuilly (1993: 388) claims, provides a range of ideological justifications to convince outsiders of the legitimacy of nationalist claims. While it is important to note the role of nationalism in justifying a state's legitimacy externally, it is also true that nationalism is a source of internal legitimacy even when, or rather because, external forces contest it. In both cases, nationalism requires well defined external or internal Other to efficiently legitimize the state. But when two sides in an internal conflict cannot de-legitimize each other on ideological grounds, the state has to reaffirm its epistemic authority through justifications cleansed of all values and emotions. In an internal conflict, when all sides share a normative ideology, nationalism cannot offer an effective basis for legitimacy.

This claim goes against the arguments of theories which see nationalism as the main force behind the justification of war waged in the name of the nation. Mosse and Smith, for example, see war as a social conflict that to great extent homogenizes and unifies the nation. The war dead in these views are mere symbols of that unity and monuments erected in their 
glory are containers of moral lessons for the future generations. The war dead indeed have a great potency as symbols. As Verdery explains (1999: 27) 'a body's materiality’ is crucial to its 'symbolic efficacy'. 'A corpse', she continues, 'can be moved around, displayed, and strategically located in specific places'. As we have seen, voices of the dead are easily ventriloquated. Hence '[h]uman bones seem always, whatever their particular context, to be exceedingly powerful representations' (Weingrod, 1995: 8). They easily become 'unnamed national heroes', 'our dead', 'Glorious Dead' or 'Unknown Warriors'.

Since bodies are such efficient symbols, there seem to be a consensus that, as McEvoy and Conway (2004: 561) argue, '[p]oliticized communities, organizations, and even states will almost inevitably incorporate their dead into their own political culture and thereby use them to reassert key themes of political ideology or political action'. Hence, it is not surprising that the question of 'who owns the dead' becomes an arena of political conflicts and confrontations. The question of who owns the dead is 'inextricably linked to the notion of who “owns” the past' (McEvoy and Conway, 2004: 545). 'Manipulating physical remains', Verdery (1999: 113) claims, 'is a visual and visceral experience that seems to offer true access to the past'.

But these explanations fail to take into account that not all of the war dead are easily mutated into national symbols. A dead body's corporeality and multivocality are not sufficient factors to allow its political manipulation. In order to transform a dead body into a symbol, the body first has to be 'de-individualized'. Only then can it be 'reframed within a constructed communal understanding of its significance' (McEvoy and Conway, 2004: 561). Even when national symbols have a "single name and a single body" (Verdery, 1999) - like Nelson, Napoleon, Garibaldi, Washington - these human beings had to be turned into national symbols. As Verdery so brilliantly showed in her analysis of post-socialist societies, these symbols were assigned multiplicity of meanings, often contradictory, and their biographies 
usually stripped of humanity, reduced to particular historical event, endowed with superpowers and turned into mythical heroes that belong to whole nation.

In the period of 1919-1921, practically no bodies were de-individualized. There were too many, some say around 200,000, that could not be identified, and there were many more names to which bodies could not be matched. Bourke (1996: 246-7) exemplifies this point when she talks about the burial of the Unknown Warrior in 1920: 'What was being represented here was not an unknown warrior - for every mother, father, sister, brother and friend recalled the face belonging to the body buried on 11 November - but the unknown grave'. In the aftermath of WWI, the bodies of the soldier dead were not symbols. Each and every one of them was mourned in some corner of the world. And as an examination of the post-war debate shows, those who were mourning were powerful social agents who actively individualized their dead and hence prevented their governments from treating the war dead as mere symbols. At that time, those human bones were not yet 'sacred symbols of the past', as Weingrod (1995: 10) likes to see them, but of the present. As cases of the USA and France tell us, whenever mourners had an opportunity, they claimed their dead. It seems that only when memories of individual lives of the dead fade away, can the dead be de-individualized and then politicized or nationalized. The dead need to lose their faces in order to become effective national symbols. Moreover, 'collective memory' [sic!] can be imbedded into the stone only once the personal memories fade away. 


\section{Notes}

${ }^{1}$ James Ellroy, cited in Verdery, 1999: 23.

${ }^{2}$ Various official and unofficial sources offer rather diverse numbers. For comparison of estimations, see http://users.erols.com/mwhite28/warstat1.htm.

${ }^{3}$ But some inequalities are more easily hidden than others. In American military cemeteries in France the fallen are buried regardless of their rank, class, creed or race. Yet, at the national cemetery in Arlington racial segregation is closely observed (Robin, 1995: 60).

${ }^{4}$ Rodney Barker (1990) defines value-rational form of legitimacy as a belief 'in the absolute validity of the order as the ultimate expression of ultimate values of an ethical, aesthetic of any other type' (cited in, Malešević, 2002: 90).

${ }^{5}$ Catering for all religious beliefs does not necessarily mean treating all these symbols equally. After all, according to the Commission's proposal each British military cemetery was to have a Cross of Sacrifice as one of its two main monuments. 


\section{Bibliography:}

Barker, Rodney. 1990. Political Legitimacy and the State. Oxford: Clarendon Press.

Breuilly, John. 1993. Nationalism and the State, $2^{\text {nd }}$ edition. Manchester: Manchester University Press.

Bourke, Joanna. 1999. Dismembering the Male: Men's Bodies, Britain and the Great War. London: Reaktion Books.

Collins, Randall. 2008. Violence: A Micro-Sociological Theory. Princeton: Princeton University Press.

Capdevila, Luc, and Voldman, Daniele. 2006. War Dead: Western Societies and the Casualties of War. Edinburgh: Edinburgh University Press.

Fussell, Paul. 1975. The Great War and Modern Memory, Oxford.

Gellner, Ernest. 1983. Nations and Nationalism. Oxford: Blackwell.

Gregory, Adrian. 1994. The Silence of Memory: Armistice Day 1919-1946. Oxford and Providence, USA: Berg Publishers.

Hardcastle, Rohan. 2007. Law and the Human Body: Property Rights, Ownership and Control. Oxford and Portland, OR: Hurt Publishing.

Hutchinson, John. 2007. 'Warfare, Remembrance and National Identity', in Athena Leoussi and Steven Grosby (eds) Nationalism and Ethnosymbolism. Edinburgh: Edinburgh University Press. 
King, Alex. 1998. Memorials of the Great War in Britain: The Symbolism and Politics of Remembrance. Oxford and New York: Berg.

McEvoy, Kieran, and Conway, Heather. 2004. 'The Dead, the Law, and the Politics of the Past', Journal of Law and Society, 31(4), pp. 539-62.

Malešević, Siniša. 2002. Ideology, Legitimacy and the New State. London: Frank Cass.

Malešević, Siniša. 2006. Identity as Ideology. New York: Palgrave Macmillan.

Malešević, Siniša. 2010. The Sociology of War and Violence. Cambridge: Cambridge University Press.

Moorhouse, G. 1992. Hell's Foundations: A Town, Its Myths and Gallipoli. London: Faber and Faber.

Mosse, George L. 1975. The Nationalization of the Masses. New York: Howard Fertig.

Mosse, George L. 1990. Fallen Soldiers. Oxford: Oxford University Press.

Riley, John W. Jr. 1983. 'Dying and the Meanings of Death: Sociological Inquiries', Annual Review of Sociology, 9, pp. 191-216.

Robin, Ron. 1995. “"A Foothold in Europe”: The Aesthetics and Politics of American War Cemeteries in Western Europe', Journal of American Studies, 29(1), pp. 55-72.

Sledge, Michael. 2005. Soldier Dead. New York: Columbia University Press.

Smith, Anthony D. 1999. Myths and Memories of the Nations. Oxford: Oxford University Press.

The Commonwealth War Graves Commission, http://www.cwgc.org (accessed: 15 August 2015) 
Verdery, Katherine. 1999. The Political Views of Dead Bodies: Reburial and Postsocialist Change. New York: Columbia University press.

Wasinski, Christophe. 2008. "“Post-Heroic Warfare” and Ghosts: The Social Control of Dead American Soldiers in Iraq', International Political Sociology, 2, pp. 113-27.

Weingrod, Alex. 1995. 'Dry Bones: Nationalism and Symbolism in Contemporary Israel', Anthropology Today, 11(6), pp. 7-12.

Winter, Jay. 1995. Sites of Memory, Sites of Mourning: The Great War in European Cultural History. Cambridge: Cambridge University Press.

Wong, Leonard. 2005. 'Leave No Man Behind: Recovering America’s Fallen Warriors', Armed Forces \& Society, 31(4), pp. 599-622.

\section{Hansard Debates}

HL Deb 9 April 1919, 'War Graves', vol. 34, cc 223-40

HC Deb 17 December 1919, ‘Imperial War Graves Commission', vol. 123, cc 485-512

HC Deb 4 May 1920, ‘Imperial War Graves Commission’, vol. 128, cc 1929-72 